\title{
THE CURRENT STATE AND THE PERSPECTIVES \\ OF FRUIT-GROWING ENTREPRENEURSHIP IN THE NORTHERN \\ DEVELOPMENT REGION OF THE REPUBLIC OF MOLDOVA
}

\section{Liliana GRINCIUC1, University Lector, State Agrarian University of Moldova}

Currently, the role and importance of SMEs in the development of the national economy are characterized by such features as: the direct contribution to the formation of the GDP in every country is, as a rule, between 55-95\%; new jobs creation; boosting competition; increasing exports; innovations and technologies fostering. The effectiveness of entrepreneurial activity in fruit growing is characterized by the application of new fruit production technologies, such as intensive and super intensive system. The purpose of the research was to analyze fruit growing entrepreneurship in the Northern Development Region of the Republic of Moldova based on the data of "Domultera” LLC in Floresti district. The objective of the research was to analyze fruit-growing entrepreneurship in the Northern Development Region of the Republic of Moldova by describing the realities and perspectives in the field. It has been found out that applying superintensive and intensive technology to fruit growing is efficient. This fact can be explained by the reduction in production costs and the increase in global fruit production, sales revenue from the obtained production and gain profit, which have influenced the increased profitability level of up to $127.76 \%$ in 2017 and $86.15 \%$ in 2018 in the case of apple cultivation by applying the superintensive system. Apples and plums cultivation by applying intensive technology also increases the economic efficiency when trees begin to bear fruits.

Keywords: entrepreneurship, efficiency, intensive technology, profitability, tree planting, seed fruits, stone fruits.

In prezent, rolul şi importanţa IMM-lor în dezvoltarea economiei naţionale se caracterizează prin unele trăsături, precum: contribuţia nemijlocită la formarea Produsului Intern Brut din orice ţară, de regulă, între 55-95\%; crearea noilor locuri de muncă; stimularea concurenţei; creşterea exporturilor; favorizarea inovaţiilor şi tehnologiilor. Eficacitatea activității de antreprenoriat în pomicultură este caracterizată de aplicarea noilor tehnologii de producere a fructelor, precum este sitemul intensiv și super intensiv. Scopul cercetării rezidă în analiza antreprenoriatului pomicol în Regiunea de Dezvoltare Nord a Republicii Moldova în baza datelor SRL „Domultera” din raionul Florești. S-a constatat că aplicarea tehnologiei super intensive cât și intensive în pomicultură poate asigura întreprinderilor un profit sporit de la 567 lei la o tonă, în anul 2016, până la 1835 lei la o tonă, în anul 2018. Aceasta se explică prin reducerea costurilor de producere și sporirea producției globale de fructe, veniturilor din vânzări de la realizarea producției și a profitului obținut, care au influențat nivelul sporit al rentabilității de până la 127,76\%, în anul 2017, și 86,15\%, în anul 2018, în cazul cultivării merelor prin sistemul super intensiv. La cultivarea merelor și prunelor prin aplicarea tehnologiei intensive, la fel, se înregistrează o sporire a eficienței economice, care se demonstrează prin rata rentabilității sporite de 48,32\% și profitul obținut în calcul la o tonă în mărime de 1225,39 lei, odată cu intrarea deplină în rod a plantațiilor.

Cuvinte-cheie: antreprenoriat, eficiență, tehnologie intensivă, rentabilitate, plantații pomicole, fructe sămânțoase, fructe sâmburoase.

В настоящее время роль и значение МСП в развитии национальной экономики характеризуется некоторыми особенностями, такими как: прямой вклад в формирование валового внутреннего продукта в каждой стране от 55\% до 95\%; создание новых рабочих мест; стимулирование конкуренции, увеличение экспорта; содействие инновациям и технологиям. Эффективность предпринимательской деятельности в выращивании фруктов характеризуется применением новых технологий производства фруктов, таких как интенсивная и интенсивная

\footnotetext{
${ }^{1}$ C Liliana GRINCIUC, Igrinciuc@gmail.com
} 
система. Цель исследования: анализ предпринимательской деятельности в области плодоводства в Северном регионе Республики Молдова на основе данных „Domultera” ОоО, Флорештского района. Было установлено, что применение суперинтенсивного и интенсивного садоводства является эффективным. Это объясняется за счет снижения себестоимости и увеличения объемов производства фруктов, доходов от реализации продукции и полученной прибыли, которые увеличили рентабельность до 127,76\% в 2017 году и 86,15\% в 2018, при выращивании яблок с применением суперинтенсивного метода. Выращивание яблок и слив с применением интенсивных технологий, также повышает экономическую эффективность, при полном входе деревьев в плодоношении.

Ключевые слова: предпринимательство, эффективность, интенсивные технологии, рентабельность, плодоводство, семечковые и косточковые фрукты.

DOI: https://doi.org/10.36004/nier.es.2019.1-05

JEL Classification: M1, M13, M21, 012, 013

UDC: $338.43+005: 634(478)$

Introduction. Under market economy conditions, the entrepreneurial activity raises a steadily increasing interest. The entrepreneurial activity has a strong impact on the world, because even if the entrepreneurs don't invent new things, they are ultimately the ones that make things move and the world progress. They are the ones who introduce new technologies, promote new products, stimulate the discovery of new resources and mobilize capital. One of the entrepreneurial activities developed in the Republic of Moldova is the cultivation of fruit plantations, the branch that has been and will be one of the priority branches of agriculture with a considerable share in the country's economy and export. The global production of fruits and berries constituted about $47 \%$ of the total national production in 2017, the main growers being Soroca, Briceni, Ocnita, Donduseni, Edinet. We can also say that global fruit production constitutes about $5 \%$ of the country's GDP.

Degree of scientific approach to the topic and its presentation in the scientific literature

The problem of fruit-growing entrepreneurship and sustainable development is studied to a certain extent in the scientists' works in the Republic of Moldova. Among the local authors, who have dedicated scientific papers to entrepreneurship, the following can be mentioned: Litvin A. in her book „Rural entrepreneurship"defines the notion of rural entrepreneurship and describes its peculiarities in rural areas. Solcan A. in her book „Small business management"defines the concept of small business and presents the functions, general principles and features of small business management. Pesteanu A. in his article "The effect of manual apple trees pruning on fruit productivity and quality"presents the results of manual apple trees pruning and demonstrates its effect on fruit productivity. Grinciuc L., Litvin A. in the article "Entrepreneurship - a major factor in the development of Moldovan economy”, describe entrepreneurship as an important factor in the development of the Moldovan economy, present the main criteria for classifying SMEs in the Republic of Moldova and analyze in dynamics some indicators that characterize the current state of SMEs. Also Grinciuc L., Bujor T. in their article "The role of entrepreneurship in the development of the economy of the Republic of Moldova", state the role of entrepreneurship in the country's economy, describe the main organizational-legal forms of entrepreneurial activity in the Republic of Moldova and present the principles of its further development.

The article is also of particular interest in the analysis of the current state of the fruit growing entrepreneurial activity in the Northern Development Region by using the data of "Domultera" LLC agricultural enterprise. On the basis of these data we can demonstrate that the application of modern technologies for cultivation of multiannual plantations contributes to the increase in fruit productivity and directly to the increase in economic efficiency.

Results of own research and discussions

Focusing on the agricultural enterprises from the Northern Development Region (NDR), it is necessary to make its brief characteristic: NDR includes Balti municipality and 11 districts: Briceni, Edinet, Donduseni, Drochia, Falesti, Floresti, Glodeni ,Ocniţa, Rascani, Singerei, Soroca, with an area of about $10,014 \mathrm{~km}^{2}$, which represents about $32.9 \%$ of the total area of the Republic of Moldova. The population is 1025 thousand people (28.6\% of the country's population), including urban population - 357 thousand people or about $34.8 \%$ of the total region. The region includes 571 localities, of which

No. 1 / 2019 
20 cities and 551 localities, out of a total of 1679 localities in the Republic of Moldova. Agriculture is an important sector in the region's economy [1;6, p.106-111].

Due to favorable climatic conditions, NDR has a significant agricultural potential in crops and yields production in particular. Of the total NDR area, 70\% is agricultural land. The region contributes with about $41 \%$ to total agricultural output of the country. The main agricultural products are cereals, technical crops and fruits. Thanks to fertile soils and favorable climate, NDR also has significant advantages in cultivating fruits and vegetables. Total production of fruits and berries in 2017 constituted $47 \%$ of the global production at the national level, the main cultivators being Soroca, Briceni, Ocnita, Donduseni, Edinet [1; 6, p.106-111].

Table 1

The surface of fruit-growing plantations, medium and global fruit harvest in the territorial regions of the Republic of Moldova

\begin{tabular}{|c|c|c|c|c|c|}
\hline \multirow{2}{*}{ Indicators } & \multicolumn{5}{|c|}{ Year } \\
\hline & 2013 & 2014 & 2015 & 2016 & 2017 \\
\hline \multicolumn{6}{|c|}{ Northern Region } \\
\hline Surface of plantations, thousands ha & 25,24 & 24,82 & 24,04 & 21,46 & 22,65 \\
\hline of which fructifying plantations & 18,82 & 20,16 & 18,36 & 16,70 & 9,25 \\
\hline Average harvest per 1 ha, $t$ & 5,81 & 7,59 & 5,89 & 6,26 & 9,07 \\
\hline Global harvest, thousands tons & 109,34 & 153,01 & 108,14 & 104,54 & 83,89 \\
\hline \multicolumn{6}{|c|}{ Central Region } \\
\hline Surface of plantations, thousands ha & 13,45 & 13,65 & 13,10 & 12,98 & 13,46 \\
\hline of which fructifying plantations & 9,72 & 9,95 & 9,86 & 9,69 & 9,82 \\
\hline Average harvest per1 ha, $t$ & 6,45 & 5,93 & 5,02 & 7,21 & 7,39 \\
\hline Global harvest, thousands tons & 62,70 & 59,00 & 49,50 & 69,86 & 72,57 \\
\hline \multicolumn{6}{|c|}{ Southern Region } \\
\hline Surface of plantations, thousands ha & 7,96 & 7,96 & 7,62 & 6,84 & 6,85 \\
\hline of which fructifying plantations & 5,36 & 4,06 & 5,80 & 5,26 & 4,83 \\
\hline Average harvest per 1 ha, $t$ & 5,45 & 5,03 & 5,08 & 8,13 & 7,73 \\
\hline Global harvest, thousands tons & 29,24 & 20,42 & 29,46 & 42,76 & 37,34 \\
\hline
\end{tabular}

Source: Elaborated by the author on the basis [1; 6, p.108].

Analyzing the data of Table 1, we can say that generally the largest areas of orchards are grown in the Central and Northern regions. In 2017 of the total of 46.14 thousand hectares of orchards in the Northern region, 22.65 thousand hectares are cultivated, out of which 9.25 thousand hectares are fructifying. It is obvious that both the total area and the fruitful surface area have been decreasing as compared to the previous years. This fact has influenced the volume of global fruit production which is decreasing compared to 2013-2016. In the Central region the situation is different: the surfaces of fruit plantations are maintained at the same level, recording an increase of the average yield per hectare, which influences the increased global fruit harvest. The same situation is recorded in the Southern region, where the surfaces are maintained at the same level, but the average harvest per hectare and the global harvest are increasing.

The production of high value crops is one of the profitable businesses that offer the best potential for revenue growth. It is also a way to escape poverty for the rural population. The European countries have had modern agriculture for decades and enormous amounts of money have been invested in agricultural business. One of the agricultural wonders in Moldova is "Domultera” LLC, which is located near Domulgeni village, Floresti district. It can be seen from a distance of several kilometers and consists of an apple orchard, which is 50 percent assured with anti-hail net, and the premises where fruits are sorted and stored. The owners invested several hundred thousand euros and it is a perfect example for those who plan to start a business in the field. The owners started the business in 2004 when they understood that only big companies would succeed in the field of acquisitions and exports. 
Three years later, when they found out that the earnings did not exceed $10 \%$ of the investment; they decided to plant an apple orchard, a business that would ensure not only income, but also maximum satisfaction. So „Domultera” LLC was born, an enterprise specialized in the production of fruits and cereals. In the structure of gross profit in 2012 cereal crops had a share of $70 \%$ and fruits $30 \%$. In the coming years, they plan to modernize their technologies and change the production structure in which the fruit will have a share of $61 \%$ and the cereals will have a share of $39 \%$. The company leased 1160 hectares of agricultural land in the village of Domulgeni, Floresti district: of which 1060 hectares were planted with field crops and 100 hectares were fruit-growing plantations. The lease contracts were concluded for a period of 10 years, except for the orchards that were leased for a period of 25 years.

The variety composition was selected by „Domultera” LLC according to the current trends in apple plantations in the EU countries.

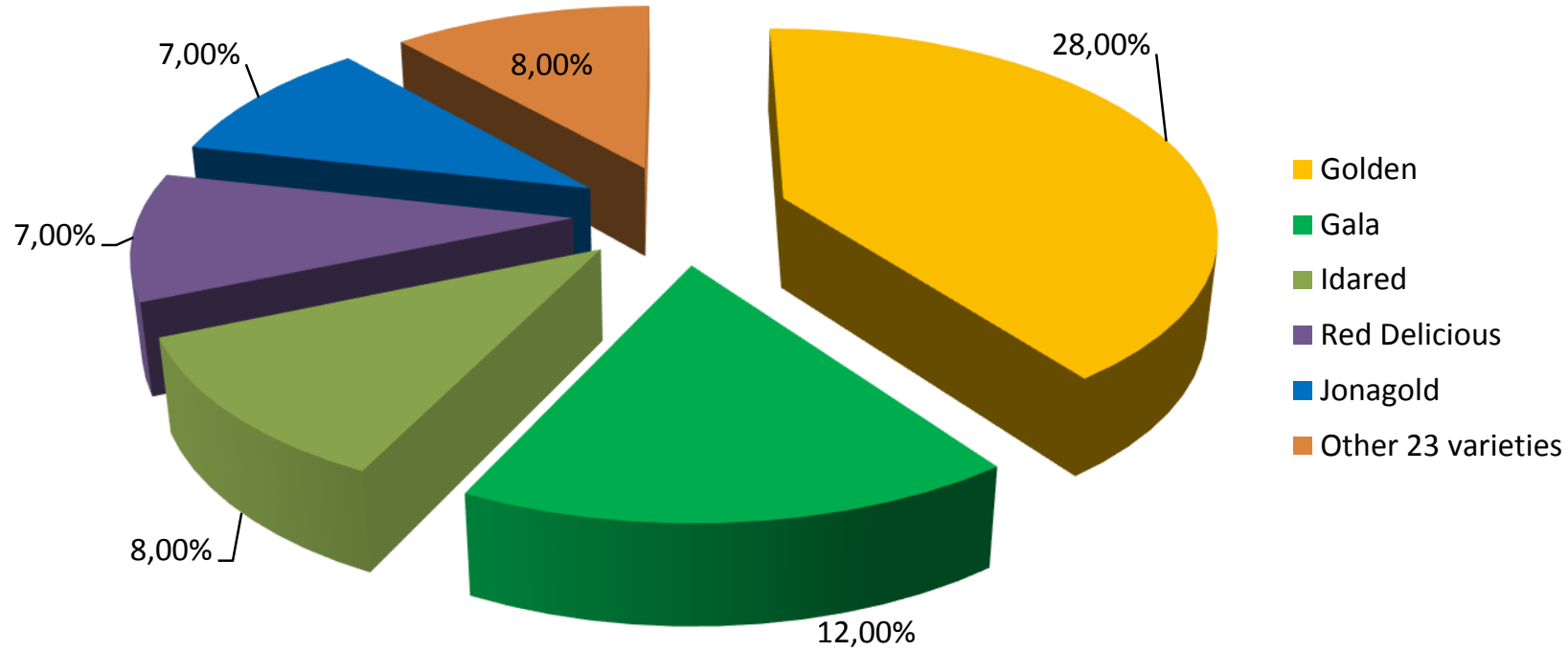

Figure 1. Top 5 varieties of apples after 2017 in the EU

Source: Elaborated by the author on the basis [8].

The data presented in Figure 1 show that consumers prefer red apple varieties. These preferences can be seen in the markets of the countries neighboring the Republic of Moldova, such as the Russian Federation or Romania, but also in the Middle East markets, where Moldovan apples have been exported recently. So among the favorite red varieties are Gala, Jonagold, Fuji Kiku, Idared, Red Delicious, etc. Red Delicious, Granny Smith, Idired and Golden Delicious are still required.

It is worth mentioning that the management of "Domultera" LLC pays great attention to its business and cultivates such high-potential varieties for exports Gala Delicious, Fuji Kiku, Golden Delicious, Granny Chalinger, Idared, Jonagold and Renette Simirenco.

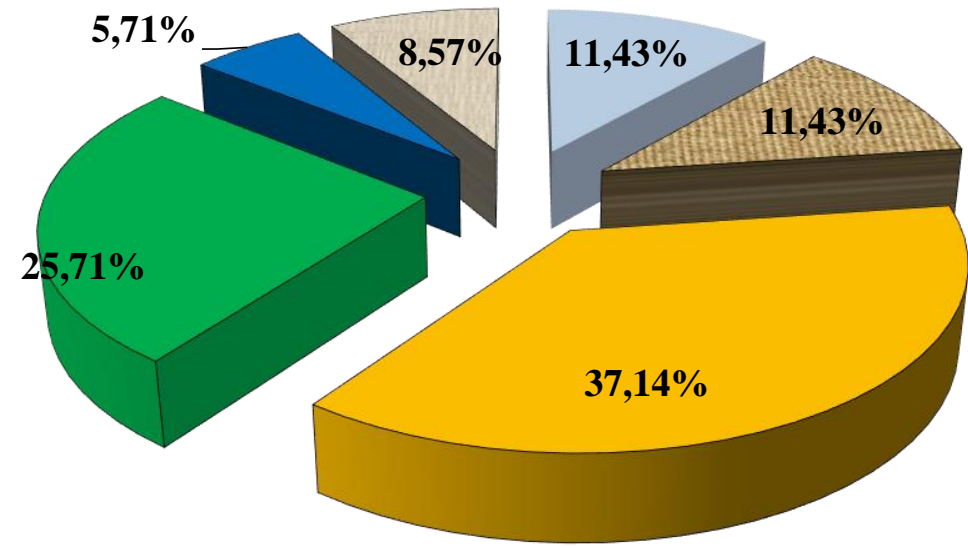

\author{
Fuji Kiku \\ ๑Granny Chalinger \\ $\square$ Golden Delicious \\ $\square$ Gala Delicious \\ 口Jonagold \\ $\square$ Simirenco
}

Figure 2. Apple varieties grown in „Domultera"LLC

Source: Elaborated by the author on the basis of the data "Domultera" LLC. 
The planting material was procured from the certified producers in Italy with 7 EUR for each rootstock and the setting up of the orchard was carried out by SC „Vitalitifruct" LLC of Moldova, which is a specialized company with many years of experience in agricultural services.

The superintensive orchard was set up on the M-9 rootstock with a density of 3750 trees per hectare on support from concrete pillars. The concrete pillars are intended to provide support:

1) for trees in the row in order to form the fruit wall;

2) for the drip irrigation and fertilization system;

3) to install hail and sun protection accessories.

The irrigation complex was built by the company during 2013 and consists of the water supply pipe from the river Raut to the fields of the enterprise and of a geomembrane accumulation basin.

The enterprise is able to market fruits for long period of time, including extra-season, using the storage capabilities of its business partner „KA-Grup” LLC, which has a modern refrigerator for fruit storage. „Domultera” LLC and „KA-Grup” LLC are related parties, mainly dealing with the marketing of apples.

Today, „Domultera” LLC owns only 70 hectares planted with orchards in the following composition: 40 hectares of apple orchards, of which 35 hectares are superintensive and 5 hectares are intensive; 15 hectares of cherries, of which: 5 hectares on the Mahaleb rootstock with 670 trees per hectare, superintensive 6 hectares on the Gizela 6 rootstock with 1667 trees per hectare and intensive 4 hectares with 1250 trees per hectare on Maxima 14 rootstock; 15 hectares of Stenley common plums with a total of 670 trees per hectare. The entire surface is irrigated, it has supporting system and 35 hectares of apple orchard are equipped with anti-hail net.

Taking into consideration the hard work and the efforts made by the owner of „Domultera” LLC, it is rational to determine the economic efficiency of the fruit production obtained by applying modern cultivation technologies.

The economic efficiency of apples production cultivated super intensively in „Domultera” LLC during the period 2015-2018

\begin{tabular}{|l|c|c|c|c|c|c|c|}
\hline \multirow{2}{*}{\multicolumn{1}{|c}{ Indicators }} & \multicolumn{4}{c|}{ Year } & \multicolumn{3}{c|}{$\begin{array}{c}\text { Year 2018 } \\
\text { in \%ompared to }\end{array}$} \\
\cline { 2 - 9 } & $\mathbf{2 0 1 5}$ & $\mathbf{2 0 1 6}$ & $\mathbf{2 0 1 7}$ & $\mathbf{2 0 1 8}$ & $\mathbf{2 0 1 5}$ & $\mathbf{2 0 1 6}$ & $\mathbf{2 0 1 7}$ \\
\hline Harvest per1 ha, t & 43,71 & 44,40 & 46,90 & 71,43 & 163,4 & 160,9 & 152,3 \\
\hline $\begin{array}{l}\text { Direct labor consumption } \\
\text { per t, man -hours }\end{array}$ & 55,67 & 62,97 & 64,51 & 49,76 & 89,38 & 79,02 & 77,14 \\
\hline The cost of 1 t, lei & 2490,00 & 2800,00 & 2356,00 & 2950,00 & 118,47 & 105,36 & 125,21 \\
\hline Selling price of 1 t, lei & 3567,00 & 3810,00 & 5446,00 & 5492,00 & 153,97 & 144,18 & 100,8 \\
\hline Profit earned per 1 t, lei & 1038,99 & 1010,00 & 3055,00 & 2542,00 & 2,44 times & 2,51 times & 83,2 \\
\hline Rate of profitability, \% & 41,10 & 36,07 & 127,76 & 86,15 & 45,0 & 50,1 & $-41,6$ \\
\hline
\end{tabular}

Source: Elaborated by the author on the basis of the data „Domultera” LLC.

The study of economic efficiency essentially involves a causal analysis of the factors that determine decision taking in the corresponding risk environment.

Thus, by analyzing the indicators of Table 2 , we can notice that the cultivation of apples by using the superintensive system on the area of 35 hectares records annually an increase of the harvest obtained per hectare. If in 2015 the harvest constituted 43.71 tons per hectare, then in the years 2016-2018 it increased to 71.43 tons, which in relative size increased respectively by $63.4 \% ; 60.9 \%$ and $52.3 \%$ in 2018 compared to the previous years.

It is good that the selling price of one tonne exceeds the cost of one tonne, which results in a profit per one tonne.

The profit per 1 tonne increased in 2018 compared to 2015 and 2016, respectively by 2.44 times and 2.51 times, which is explained by the increase of the income obtained from the production.

All these results influenced the rate of profitability that increased in 2018 compared to 2015 and 2016 by 45.0 p.p. and 50.1 p.p respectively, and compared with 2017 it decreased by 41.6 p.p, the 
cause being the increase in production costs and the non-marketing of total fruit production.

This data demonstrates that in "Domultera"LLC it is efficient to produce apples using superintensive cultivation technology.

Table 3

The economic efficiency of apples production intensively cultivated in „Domultera” LLC during 2016-2018

\begin{tabular}{|l|c|c|c|c|c|}
\hline \multirow{2}{*}{\multicolumn{1}{|c|}{ Indicators }} & \multicolumn{3}{c|}{ Years } & Year 2018 in \% comparison to \\
\cline { 2 - 6 } & $\mathbf{2 0 1 6}$ & $\mathbf{2 0 1 7}$ & $\mathbf{2 0 1 8}$ & 2016 & 2017 \\
\hline Harvest per 1 ha, t & 17,40 & 8,20 & 27,40 & 157,47 & 3,3 times \\
\hline $\begin{array}{l}\text { Direct labor consumption per t, man } \\
\text {-hours }\end{array}$ & 51,49 & 52,29 & 53,00 & 102,93 & 101,36 \\
\hline The cost of one t, lei & 3000,00 & 3243,90 & 3165,00 & 105,50 & 97,57 \\
\hline Selling price of 1 t, lei & 3567,01 & 3809,02 & 5000 & 140,2 & 131,26 \\
\hline Profit earned per1 t, lei & 567,00 & 565,12 & 1835,00 & 3,23 times & 3,25 times \\
\hline Rate of profitability, \% & 18,90 & 17,42 & 52,96 & 34 & 35,5 \\
\hline
\end{tabular}

Source: Elaborated by the author on the basis of the data „Domultera” LLC.

Another statistical situation is reflected in Table 3 which presents the data on apples cultivation on the area of 5 hectares by using the intensive system during three years. This situation is explained by the fact that the intensively cultivated apple orchard has born fruits since 2016. It is well known that the achievemnt of an investment goal has the purpose to achieve a certain effect, but the effects have a complementary character, influencing each other, and the determination of efficiency is done by aggregating all the effects.

Therefore, in the process of growing apples by using the intensive system, which consists of the application of the dripping system only, the same good results are obtained. If a harvest of 17.4 tonnes per hectare was obtained in the first year of harvest, then in the third year there were 27.4 tonnes per hectare or $57.47 \%$ more than in 2016.

The cost of one tonne of apples decreased by $2,41 \%$ in 2018 compared to 2017 due to the effect of the "economy of scale" principle, i.e. by increasing global apple production.

The increase in the price of production in 2018 compared to the previous years was by $40.06 \%$ and $31.23 \%$, respectively, it directly influenced the obtained profit increase per one tonne of apples.

The profitability rate is increasing by 34 p.p in 2018 compared to 2016 and by 35.5 p.p compared to 2017, which is, in fact, the expected goal of all economic agents as a result of investment works for development, modernization and refurbishment of the production process.

Table 4

The economic efficiency of the production of plums grown in „Domultera” LLC during 2016-2018

\begin{tabular}{|l|c|c|c|c|c|}
\hline \multirow{2}{*}{\multicolumn{1}{|c|}{ Indicators }} & \multicolumn{3}{c|}{ Years } & \multicolumn{2}{c|}{$\begin{array}{c}\text { Year 2018 } \\
\text { in \% comparison to }\end{array}$} \\
\cline { 2 - 6 } & $\mathbf{2 0 1 6}$ & $\mathbf{2 0 1 7}$ & $\mathbf{2 0 1 8}$ & $\mathbf{2 0 1 6}$ & $\mathbf{2 0 1 7}$ \\
\hline Harvest per 1 ha, t & 2,42 & 6,22 & 14,96 & 6,2 times & 2,4 times \\
\hline $\begin{array}{l}\text { Direct labor consumption per t, } \\
\text { man -hours }\end{array}$ & 55,67 & 51,49 & 48,66 & 87,4 & 94,50 \\
\hline The cost of one t, lei & 2875,00 & 2057,00 & 2535,00 & 88,17 & 123,2 \\
\hline Selling price of 1 t, lei & 3338,80 & 3169,45 & 3761,13 & 112,65 & 118,67 \\
\hline Profit earned per 1 t, lei & 463,61 & 1111,86 & 1225,39 & 2,6 times & 110,2 \\
\hline Rate of profitability, \% & 16,12 & 54,04 & 48,32 & 32,2 & $-5,7$ \\
\hline
\end{tabular}

Source: Elaborated by the author on the basis of the data „Domultera” LLC.

The level of economic efficiency is higher when the useful effect per unit of made effort is greater or when the consumed effort per unit of useful effect is lower. 
Thus, analyzing the indicators of the economic efficiency of plum production grown in „Domultera” LLC during the period 2016-2018, we've found out that the made effort generated the expected effects.

In the dynamics of the analyzed period there was a considerable increase of the plum harvest per hectare, as well as the increase in labor productivity as a result of the promotion of new technologies through refurbishment and re-engineering works.

Although the rate of profitability in 2018 decreased by 5.7p.p. compared to 2017, the plum production is effective.

So, through its activity and its results, „Domultera” LLC has proved to be an important actor of the agricultural business in the Northern region of the republic with regard to the production and marketing of fruits. And the positive dynamics of market development and business relationships have prompted the company to modernize its fruit production sectors in order to maximize profit.

The analysis of the situation in this domain allows us to recommend some directions, levers and tools that would support the sustainable development of the fruit-growing business:

$>$ local producers should orient towards the establishment of spring-frost-resistant seedlings of stone fruit trees, which enjoy an increased demand on the market and the weather conditions of the country in recent years;

$>$ domestic producers should start competing with the fruit growers from Peru, South Africa, etc. by using advanced technologies and competitive varieties, by developping post-harvest infrastructure and having the desire to be better;

$>$ organization of conferences and seminars with the participation of a number of foreign experts who have rich experience in advanced technologies, which would allow local fruit growers to learn more about new production and processing technologies, fruit preservation, to become familiar with the branch development strategy in the context of the EU integration and the evolution of business forecasts and strategies;

$>$ another way of the sustainable development of fruit growing business would be to join a target group of beneficiaries belonging to projects and programs, supporting people who wish to invest in the launching and/or developing of their own business.

In this context, I would like to mention that the majority of fruit growers who cultivate intensive and superintensive orchards are pioneers in this field and must also be competitive on the local market. The local consumer must have a choice and should be treated with respect and the fruits grown in the orchard of Moldova must promote the consumption of tasty and healthy apples as a source of vitamins and a symbol of national agriculture.

Conclusions

Under the conditions of market economy the role of entrepreneurial activity is very important in the Republic of Moldova. One of the priorities of the development of fruit-growing entrepreneurship in the Republic of Moldova is the cultivation of fruit plantations with the application of modern technologies, which ensure the competitiveness of domestic production on the foreign agricultural markets.

„Domultera”LLC is a well-known agricultural enterprise both in the Republic of Moldova and abroad as it applies modern technologies for the production of seed fruits and stone fruits. From the company's primary information and the calculations we've made, we've found out that in "Domultera" LLC the cultivation of fruit plantations by applying super intensive and intensive technology is efficient. This fact is explained by the reduction in production costs and the increase in overall fruit production, sales revenue from production and profit, which have affected the increased profitability level of up to $127.76 \%$ in 2017 and $86.15 \%$ in 2018 in the case of apple cultivation by using the super intensive system. In the cultivation of apples and plums by applying intensive technology there is also an increase in economic efficiency when the trees bear fruits, which resulted in the increase of profitability rate from $16.12 \%$ in the first year of bearing to $54,04 \%$ in the second year of bearing.

It can be stated with certainty that the practice of today's modern technologies in fruit growing creates conditions for sustainable development, which represents a long-term activity, i.e. ensuring the future in order to avoid insolvent problems in the business and in the life of the "actors" of the given domain. 


\section{REFERENCES}

1. Agriculture. National Bureau of Statistics. [Accesat 10.11.2018]. Disponibil: http://statistica.gov.md/category.php?l=ro\&idc=129

2. Entrepreneurship. National Bureau of Statistics. [Accesat 25.02.2019]. Disponibil: http://statistica.gov.md/category.php?l=ro\&idc=368

3. CATANOI, Valentina, COTELNIC, Ala, BUGAIAN, Larisa. Antreprenoriat: iniţierea afacerii. Chişinău: "Elena V.I.", 2010. 344 p. ISBN 978-9975-9649-4-4.

4. BUJOR Tatiana, GRINCIUC Liliana. Rolul antreprenoriatului în dezvoltarea economiei Republicii Moldova. In: Politici economice și financiare pentru o dezvoltare competitivă: conferinţa ştiinţifică internaţională. Chişinău: ULIM, 2013, pp. 79-84. ISBN978-9975-124-30-0. [Accesat 10.11.2018]. Disponibil: http://dspace.uasm.md/bitstream/handle/123456789/1942/p.7984_bujor.pdf?sequence=1\&isAllowed=y

5. Societatea comercială "Domulterra" SRL. [Accesat 10.11.2018]. Disponibil: https://www.infodebit.md/?info_biz=1\&idnp=1007607000623

6. GRINČUK, Liliana. Analiz proizvodstva fructov $v$ severnom regione Respubliki Moldova. V: Aktual'nye naučnye issledovaniâ v sovremennom mire. 2018, № 6, čast' 4, ss. 106-111. ISSN 2524-0986

7. GRINCIUC, Liliana, LITVIN, Aurelia. Entrepreneurship - a major factor in the development of the Moldovan economy. In: Management, Economic Engineering in Agriculture and Rural Development. Bucharest, 2013, vol. 13, pp. 175-181. ISSN 2284-7995.

8. Diversitatea soiurilor de măr - cel mai consumat fruct din lume. 2016, 19 septembrie. [Accesat 10.11.2018]. Disponibil: https://madein.md/news/drumul-fructelor/diversitatea-soiurilor-demar-cel-mai-consumat-fruct-din-lume

9. LITVIN, Aurelia. Antreprenoriatul rural. Chişinău: UASM, 2003. 271 p. ISBN 9975-946-70-4.

10. PEŞTEANU, Ananie. Efectul răririi manuale a merelor asupra productivităţii şi calităţii fructelor. In: Lucrări Ştiinţifice. Horticultură, viticultură, silvicultură şi protecţia plantelor. Chişinău, 2008, vol. 16. pp. 83-86. ISBN 978-9975-64-125-8.

11. SOLCAN, Angela. Managementul micului business. Chişinău: Ed. ASEM, 2001. 301 p. ISBN 997575-131-8.

Recommended for publication: 24.06.2019 